\title{
Marketing Mix Effect and Quality Product Purchase Decision on Rice Pandaraman in South Tapanuli Region
}

\author{
Mei Linda Sipayung ${ }^{1}$, Asmina Herawaty Sinaga ${ }^{2}$ \\ ${ }^{I}$ Department of Agribusiness, Universitas Sisingamaraja XII, Jl. Perintis Kemerdekaan No.9, Perintis, Medan \\ Timur., Kota Medan, Sumatera Utara 20234, Indonesia \\ ${ }^{2}$ Department of Agribusiness, Universitas Darma Agung, Jl. Dokter TD Pardede No.21, Petisah Hulu, Medan \\ Baru, Kota Medan, Sumatera Utara 20153, Indonesia
}

\begin{abstract}
One of the factors that influence purchasing decisions by consumers is the marketing mix and product quality. The rice producers Pandaraman doing marketing mix for their products that lead to purchase decisions by consumers and always look at the quality of product to production. The result is a combination of marketing and product quality simultaneously powerful and significant influence on purchasing decisions Pandaraman rice employees in South Tapanuli region. Marketing mix variables most dominant in improving employee purchasing decisions Pandaraman rice in South Tapanuli region. Partially each variable marketing mix and product quality and significant positive influence on purchasing decisions Pandaraman rice employees in South Tapanuli region. The coefficient of determination (R2) of the marketing mix variables and product quality able to explain the purchase decision Pandaraman rice employees in South Tapanuli region amounted to $66.8 \%$ while the independent variables explain the remaining $33.2 \%$ were not examined
\end{abstract}

Keyword: Marketing Mix, Product Quality, and Purchasing Decisions

\section{Introduction}

Rice is the food most consumed by the people of Indonesia. Rice becomes crucial in Indonesia for 90 percent of the Indonesian people consume rice (Media Centre, 2013). According to Purnomo and Purwaningsih (2013), of the total energy consumed by the people of Indonesia, nearly 60 percent satisfied by rice, it is proved that the people of Indonesia will need vast rice. National Social Economic Survey by the Central Statistics Agency (BPS) in 2015 mentioned that the consumption of rice per capita per March 2015 is equal to 98 kilograms per year. This number has increased over the previous year is only $97.2 \mathrm{~kg}$ per year. Per capita consumption was assessed based on dishes containing rice include rice consumption in the form of rice, glutinous rice, rice flour and other grain consumption. Also, foodstuffs containing other rice taken into account is rice noodles, baby food packaging, cake, rames rice, fried rice, white rice, and vegetable rice cake. Consumption of rice according to the survey, a nationally per year to reach Rp 64 thousand. This expenditure value becomes greater for rural areas, amounting to $\mathrm{Rp} 71$ thousand and the average urban $\mathrm{Rp} 57$ thousand in urban areas. Based on the Central Bureau of Statistics South Tapanuli Harvested Area, Average Productivity and Production of Paddy and Palawija according to the type of plant in 2015 as follows:

TABLE 1: Harvested Area, Average Productivity, and Production of Paddy and Palawija

\begin{tabular}{|c|c|c|c|}
\hline Type of Plant & Harvest Area (Ha) & Yield Rate $(\mathrm{Kg} / \mathrm{Ha})$ & Production (Ton) \\
\hline (1) & (2) & (3) & (4) \\
\hline WetLand Paddy & 32,281 & 50,18 & 161,999 \\
\hline Dry Land Paddy & 2,352 & 37,01 & 8,704 \\
\hline Wet and Dry Paddy & 34,633 & 49,29 & 170,703 \\
\hline
\end{tabular}

Rice is the primary item that is the human need, but purchases of rice are always seemed to be the main item for some people. The consumers of rice have different reasons to consume rice. Many reasons are affecting the consumer to consume rice. More and more brands of rice that circulated in Medan making consumers more careful in choosing products that manufacturers should pay attention to product quality in order not to compete with other products. Also, an appropriate price factor and obtaining the product can also influence the purchase decision. Vigorous promotion of a product can make consumers more interested and want to know the types of products and ultimately choose the product. Various attempts were made to maintain the company's brand image, and market share has been achieved, including technological innovation. Advantages of such products, pricing and promotions targeted. The better the brand image of a product sold will have an impact on purchasing decisions by consumers. However, many companies do not realize that building a brand image in the minds of consumers is not merely through advertising and promotions alone. Other factors also have a major impact, as well as product packaging design, including the contents of text/message on the packaging, features/facilities 
contained in the product, and more and more related to the quality of the product. The assessment influences the decision to buy a product will shape the quality of the product. Demands will require a more qualified goods make companies engaged in various business sectors vying improve the quality of their goods to maintain brand image of products they have. The brand has a specific nature and characteristics which distinguish with other products, although the products were similar. Until now, Rice Pandaraman is still a demanding public. Consumer behavior is a process, and the purchase is only a stage. By understanding consumer behavior, the company gained much input in determining its marketing strategy. The marketing strategy consists of elements of integrated marketing known as the marketing mix, i.e., product, price, promotion, the place is always evolving in line with the movement of companies and changes in the marketing environment as well as changes in consumer behavior. Marketing strategy involves two basic marketing activities, the choice of markets will be targeted marketing and formulate and develop an appropriate combination of factor product, price, promotion, and distribution so that customer needs could be met satisfactorily. Create a quality or meet the expectations of consumers with a cheap price with good quality offered, and also rice products Pandaraman also maximizes the ability to undertake promotional activities or relationships with the public, so despite not being a leader in market share in the industrial rice, but the rice brand Pandaraman managed to become the head of the top brand of rice.

\section{A. Marketing mix}

\section{Theories}

Kotler (2005: 25) states that "The marketing mix is a set of marketing tools used by companies to continuously achieve its marketing objectives in the target market marketing tools are classified into four broad group called the four "that is product, price, place and promotion ". Lamb, et.al. (2001: 20) states that "The marketing mix is a blend of product strategy, promotion, place, and price that are uniquely designed to produce mutually satisfactory exchanges with the intended market." However, according to Lupiyoadi (2001: 28) describes the terms of the above definition of the marketing mix for a product tangible goods. Marketing mix for product items include 4Ps, namely Product, Price, Place, and Promotion.

\section{B. Product quality}

The product is the core of business activity because the product was sold to consumers for profit, Tjiptono (2008) states that the product is anything (goods, services, people, places, ideas, information, organization) that can be offered to satisfy the needs or desires of consumers. The quality of products according to Kotler (2008) are the characteristics possessed by a product or service in its ability to satisfy customer needs. Mowen et al. (2002) found that product quality has a direct influence on customer satisfaction. Meanwhile, according to Tjiptono (2008), a quality product is defect-free goods and products by the standards can be defined and measured. The quality of the goods has eight key dimensions (Tjiptono, 2008), namely: 1. Performance, 2. Features, 3. Reliability, 4. Confirmation, 5. Durability, 6. Serviceability 7. Aesthetics, 8. Perception of Quality.

\section{Buying decision}

Purchasing decisions of consumers is a mental statement to reflect the planned purchase some products with a particular brand. Knowledge of purchasing decisions is indispensable marketers to know the intentions of consumers towards a product or to predict consumer behavior in the future (Setiadi 2003: 167). Kotler (2005: 227) defines a purchase decision is a decision or desire of consumers that can form the intention to buy the most preferred product. Likewise, Chandra (2005: 51) defines the purchasing decision of consumers need information about products for decision-making.

\section{Evaluation}

Location of this research in South Tapanuli region consists of 6 (six) villages, and the object of research used in this study is the residents who consume rice. The research would be conducted in South Tapanuli area is composed of 12 (twelve) districts and this research conducted in 2016.

The population in this study were people who consume rice with unknown number, with certainty so as to calculate the minimum required number of samples using lemeshow formula for unknown population.

$\mathrm{n}=\mathrm{Z}^{\wedge} 2 \mathrm{P}(1-\mathrm{P}) / \mathrm{d}^{\wedge} 2$

Where

$\mathrm{z}=1.96, \mathrm{p}=$ maximal estimate $=0.5, \mathrm{~d}=$ alpha $(0: 05)$

Therefore

$1.96^{\wedge} 2.0 .5(1-0.5) / 0.05^{\wedge} 2=384$ 
Description: $\mathrm{n}=$ number of samples $\mathrm{z}=\mathrm{z}$ score at $95 \%=1.96 \mathrm{p}=$ maximum estimate $=0.5 \mathrm{~d}=$ alpha $(0.05)$ or sampling error $=5 \%$ so that if the formula is then obtained is $n 384$ so that at least the authors of this study should take data from a sample of at least 384 people.

Model data analysis in this research is multiple linear regression analysis were used to determine the influence of the independent variables were the number two or more (X1 and X2) to the dependent variable (Y). To measure the effect of independent variables on the dependent variable used multiple linear regression analysis using SPSS software version 21.0

Hypothesis Testing:

$$
\mathrm{Y}=\mathrm{a}+\mathrm{b} 1 \mathrm{X} 1+\mathrm{b} 2 \times 2+\mathrm{e}
$$

a. Simultaneous Test (Test F)

b. Partial test (t-test)

c. The coefficient of determination (R2

1. Multiple Linear Regression Model

Multiple linear regression analysis was used to test hypotheses about the influence of marketing mix variables and product quality too variable purchase decision. Based on the results of multiple linear regression equations obtained the results as shown in Table 2:

TABLE 2: Multiple Linear Regression Test Results

\begin{tabular}{|c|c|c|c|c|c|}
\hline \multirow{2}{*}{ Model } & \multicolumn{2}{|c|}{ Unstandardized Coefficients } & $\begin{array}{c}\text { Standardized } \\
\text { Coefficients }\end{array}$ & \\
\cline { 2 - 6 } & $\mathrm{B}$ & Std. Error & Beta & $\mathrm{t}$ & Sig. \\
\hline Constant & 2.025 & .719 & & 2.817 & .005 \\
\hline $\mathrm{X} 1$ & .321 & .031 & .477 & 10.262 & .000 \\
\hline $\mathrm{X} 2$ & .443 & .049 & .421 & 9.044 & .000 \\
\hline Dependent Variable: Y
\end{tabular}

Based on Table 2, the multiple linear regression equation in this study as follows

2. The coefficient of determination (R2)

$$
\mathrm{Y}=2,025+0,321 \mathrm{X}_{1}+0,443 \mathrm{X}_{2}
$$

The coefficient of determination is determined by the adjusted R-square can be seen in Table 3:

TABLE 3: Value Coefficient of Determination (R Square)

\begin{tabular}{|c|c|c|c|c|}
\hline Model & $\mathrm{R}$ & $\mathrm{R}$ Square & Adjusted R Square & Std. Error of the Estimate \\
\hline 1 & $.819 \mathrm{a}$ & .670 & .668 & 2.06001 \\
\hline
\end{tabular}

Based on Table 2 above adjusted R Square is 0.668 means that the ability of the marketing mix variables and product quality can explain the variation of purchasing decisions is $66.8 \%$ while the independent variables explain the remaining $33.2 \%$ were not examined.

\section{Test F (Simultaneous)}

Simultaneous test / F-test was conducted to determine the level of positive and significance of marketing mix variables and product quality, the variable purchase decision could be seen in Table 4:

\begin{tabular}{|c|c|c|c|c|c|}
\hline Model & Sum of Square & Df & Mean Square & $\mathrm{F}$ & Sig. \\
\hline Regression & 2339.613 & 2 & 1169.807 & 275.661 & $.000^{\mathrm{a}}$ \\
\hline Residual & 1150.025 & 271 & 4.244 & & \\
\hline Total & 3489.639 & 273 & & & \\
\hline \multicolumn{5}{|c|}{ a. Predictors: (Constant), X2, X1 } & \\
\hline \multicolumn{5}{|c|}{ b. Dependent Variable: Y } & \\
\hline
\end{tabular}

TABLE 4: Results of Simultaneous Hypothesis Testing / Test F

From table 4 the results obtained F count 275.661 while the $F$ table at $\alpha=0.05$ with 2 degrees of the numerator and denominator degrees $\mathrm{F}$ table 271 gained 3,07. From these results known $\mathrm{F}$ count $>\mathrm{F}$ table and significance of 0.000 or less than $\alpha=0.05$. Thus, the position of the importance of test points that are in the area or could be inferred rejection of $\mathrm{H} 0 \mathrm{H} 1$ accepted which means that the variables of the marketing mix and product quality together active and significant impact on the purchase decision variables. 
4. T-test (Partial)

The results of partial hypothesis testing could be seen in Table 5:

TABLE 5: Hypothesis Partial Test Results / Test-t

\begin{tabular}{|c|c|c|c|c|c|}
\hline \multirow{2}{*}{ Model } & \multicolumn{2}{|c|}{ Unstandardized Coefficients } & $\begin{array}{c}\text { Standardized } \\
\text { Coefficients }\end{array}$ & \multicolumn{2}{|c|}{} \\
\cline { 2 - 6 } & $\mathrm{B}$ & Std. Error & Beta & $\mathrm{t}$ & Sig. \\
\hline Constant & 2.025 & .719 & & 2.817 & .005 \\
\hline $\mathrm{X} 1$ & .321 & .031 & .477 & 10.262 & .000 \\
\hline $\mathrm{X} 2$ & .443 & .049 & .421 & 9.044 & .000 \\
\hline Dependent Variable: Y
\end{tabular}

From Table 5 the partial test results obtained the following results:

T-count value to the marketing mix variables of 10.262 is greater than the value of the t-table (1.65) or sig $\mathrm{t}$ for the variable purchase decisions $(0,000)$ is smaller than alpha $(0.05)$. $\mathrm{T}$-count value for the variable quality of the product amounted to 9.044 greater than the t-table value (1.65) or sig t to the variable quality of the product $(0,000)$ is smaller than alpha $(0.05)$. Based on the results obtained then reject $\mathrm{H} 0$ and accept $\mathrm{H} 1$ to the variable quality of the product. Thus, the partial product quality and significant positive influence on purchasing decisions. The product gives the sense that with the quality of the product have an impact on the increase in the purchasing decision. Partially marketing mix variables are dominant in influencing purchasing decisions. That is marketing mix variables is crucial in increasing the purchasing decision compared to the quality of products.

\section{Conclusion}

Based on the results of research and discussion that has been described in the previous chapter it can be concluded as follows:

1. The marketing mix and product quality simultaneously active and significant influence on purchasing decisions Pandaraman rice employees in South Tapanuli region. Marketing mix variables most dominant in improving employee purchasing decisions Pandaraman rice in South Tapanuli region.

2. Partially each variable marketing mix and product quality and significant positive influence on purchasing decisions Pandaraman rice employees in South Tapanuli region.

3. The coefficient of determination (R2) of the marketing mix variables and product quality able to explain the purchase decision Pandaraman rice employees in South Tapanuli region amounted to $66.8 \%$ while the independent variables explain the remaining $33.2 \%$ were not examined

\section{References}

[1]. Aritonang, R. Lerbin, R. 2007. Teori dan Praktik Riset Pemasaran. Bogor: Ghalia Indonesia.

[2]. Chandra, G. 2005. Strategi dan Program Pemasaran. Edisi Kedua. Yogyakarta : Andi.

[3]. Ghozali, Imam. 2005. Aplikasi Analisis Multivariate dengan Program SPSS. Semarang : Badan Penerbit Universitas Diponegoro.

[4]. Kotler, Philip. 2004. Manajemen Pemasaran : Analisis, Perencanaan, Implementasi dan Kontrol. Edisi Sebelas. Alih Bahasa, Hendra Teguh. Jakarta : PT. Prenhallindo.

[5]. Kotler, Philip dan Amstrong, Garry. 2008. Prinsip-prinsip Pemasaran. Jilid 1. Jakarta : Erlangga

[6]. Kotler, Philip dan Keller. L. Lane. 2006. Manajemen Pemasaran. Jakarta : Ghalia Indonesia.

[7]. Kotler, Philip dan Keller. L. Lane. 2009. Manajemen Pemasaran. Edisi Ketiga belas, Terjemahan Bob Sabran. Jakarta : Erlangga.

[8]. Kotler, Philip. 2005. Manajemen Pemasaran. Jilid 1 dan 2. Jakarta : PT. Indeks Kelompok Gramedia.

[9]. Kuncoro, Mudrajat. 2003. Metode Riset untuk Bisnis dan Ekonomi. Jakarta : PT. Gramedia Pustaka.

[10]. Lamb, Charles. W. 2001. Pemasaran. Buku I. Edisi Pertama. Jakarta : Salemba Empat.

[11]. Lupiyoadi, Rambat. 2001. Manajemen Pemasaran Jasa Teori dan Praktik. Jakarta : Salemba Empat.

[12]. Morissan, 2010. Periklanan : Komunikasi Pemasaran Terpadu. Jakarta : Prenada Media Group.

[13]. Payne, Adrian. 2001. The Essence of Service Marketing. Diterjemahkan oleh : Fandy Ciptono. Yogyakarta: Andi.

[14]. Peter, J. Paul dan Olson. C. Jerry. 2000. Consumer behavior : Prilaku Konsumen dan Strategi Pemasaran. Jilid I. Edisi Keempat. Jakarta : Erlangga.

[15]. Purwono dan Purwaningsih .H. 2013. Budidaya 8 jenis tanaman pangan unggul. Penebar Swadaya. Jakarta.

[16]. Pusdatin (Pusat Data dan Sistem Informasi Pertanian), 2013, Buletin Konsumsi Pangan Vol 4(2): 8-18.Pusat Data dan Sistem Informasi Pertanian. Jakarta. Sastradipoera, Komaruddin. 2003. Manajemen Marketing ; Suatu Pendekatan Ramuan Marketing. Bandung : Kappa Sigma.

[17]. Setiadi, Nugroho. 2003. Prilaku Konsumen dan Implikasi untuk Strategi dan Penelitian Pemasaran. Cetakan Pertama. Jakarta : Prenada Media.

[18]. Stanton, William, J. 2000. Prinsip Pemasaran. Edisi revisi. Jakarta : Erlangga.

[19]. Sugiyono. 2003. Metode Penelitian Bisnis. Cetakan Kelima. Bandung : Alfabeta.

[20]. Sugiyono. 2006. Metode Penelitian Kuantitatif, Kualitatif dan R\&D. Bandung : Alfabeta.

[21]. Sugiono. 2011. Statistika untuk Penelitian. Bandung : Alfabeta.

[22]. Sunarto. 2004. Prinsip-prinsip Pemasaran. Yogyakarta : Amus.

[23]. Tjiptono, Fandy. 2008. Strategi Pemasaran. Yogyakarta : Andi.

[24]. Yazid. 2001. Pemasaran Jasa : Konsep dan Implementasi. IKAPI. Jakarta : PT. Gramedia Pustaka Utama. 
[25]. Saputra, Hendra. 2008. Analisis Pengaruh Stratregi Bauran Pemasaran terhadap Keputusan Pembelian Teh Celup Sariwangi oleh konsumen Rumah Tangga di Kota Medan.

[26]. Sianturi, Kristin. 2006. Analisis Faktor-faktor yang Mempengaruhi Keputusan Pembelian Rumah pada Perumahan Citra Wisata Medan

[27]. Quddus, Faisal. 2013. Pengaruh Bauran Pemasaran terhadap Keputusan Pembelian Mobil Toyota pada PT. Astra International Tbk cabang Medan Amplas.

[28]. Rochman, Fachrur. 2013. Pengaruh Strategi Bauran Pemasaran terhadap Keputusan Pembelian pada UD. Arkani Furniture di Medan. 